\section{Immunohistochemical localization of IGF-I, IGF-II and MSTN proteins during development of triploid sea bass (Dicentrarchus labrax)}

\author{
G. Radaelli, ${ }^{1}$ C. Poltronieri, ${ }^{1}$ \\ C. Simontacchi, ${ }^{1}$ E. Negrato, \\ F. Pascoli, ${ }^{1}$ A. Libertini,, ${ }^{2}$ D. Bertotto'
}

'Department of Experimental Veterinary

Sciences, University of Padua, Italy

${ }^{2}$ Institute of Marine Science (ISMAR),

Venice, Italy

\section{Abstract}

The cellular localization of IGF-I, IGF-II and MSTN proteins was investigated during ontogenesis of triploid sea bass (Dicentrarchus labrax) by an immunohistochemical approach. The results were compared with those observed in diploids. IGF-I immunostaining was mainly observed in skin, skeletal muscle, intestine and gills of both diploids and triploids. From day 30 of larval life, IGF-I immunoreactivity observed in skeletal muscle, intestine, gills and kidney was stronger in triploids than in diploids. At day 30 , triploids exhibited a standard length significantly higher than the one of diploids. Although IGF-II and MSTN immunoreactivity was detectable in different tissues and organs, no differences between diploids and triploids were observed. The spatial localization of IGF-I, IGF-II and MSTN proteins detected in this study is in agreement with previous findings on the distribution of these proteins in diploid larvae and fry. The highest IGF-I immunoreactivity observed in triploids suggests a possible involvement of ploidy in their growth performance.

\section{Introduction}

In the last years, the use of chromosome set manipulation techniques to induce triploidy has been employed to increase growth performance in both freshwater and marine fish species. ${ }^{1.5}$ Although triploids are morphologically similar to diploids, they are functionally sterile and may give economical advantage of a potential faster post-puberal growth. ${ }^{6}$ However, comparing the growth performance between triploid and diploid animals, different results have been observed in relation to the species examined, the age and the rearing conditions. ${ }^{7}$ The European sea bass (D. labrax) is a marine teleost fish of great interest in aquaculture, due to its meat quality and the large size that it can reach. Sea bass represents one of the numerous marine species that has been subjected to triploidization ${ }^{3,8-9}$ in order to study the growth performance. ${ }^{7}$ By evaluation of body weight, Felip et al.,10 observed that in juveniles, diploids reached similar growth rates as those of triploids, whereas adult triploids grew slower than adult diploids although they exhibited similar fork length. No papers report on the cellular localization of growth factors such as IGFs and MSTN during ontogenesis of triploid fish.

It is well known that a complex of endo-, para- and autocrine ways of action regulates growth. In fish, the Insulin-like Growth Factor (IGF) complex and myostatin (MSTN) play a key role in the growth regulation. ${ }^{11-14}$ The IGF complex includes the two highly conserved primary ligands, IGF-I and IGF-II, high-affinity transmembrane receptors that belong to the insulin/IGF receptor family and six IGFbinding proteins (IGFBP-1 to -6 ) ${ }^{15-17}$ IGF-I is produced mainly in the bony fish liver, although numerous other organs express this molecule as well. ${ }^{16,18-28}$ IGF-II shows structural sequence similarity to IGF-I and in fish exhibits an ubiquitous expression, where it acts mainly as a growth factor. . $^{21,25,27,29-40}$ Myostatin (MSTN) is a member of the TGF- $\beta$ superfamily and in fish its expression has been observed in several organs such as brain, eyes, exocrine and endocrine pancreas, gills, gonads, heart, intestine, kidney, liver, oesophagus, pharynx, skin, spleen, stom$\operatorname{ach}^{12,41-53}$ and muscle fish explants. ${ }^{54}$

Since the data concerning the growth performance of triploids are mainly focused on body weight and fork length, the aim of this study was to evaluate whether diploid and triploid sea bass (D. labrax) differed in terms of immunohistochemical localization of IGF-I, IGF-II and MSTN proteins. For this purpose, the cellular sites of protein distribution were examined during development and growth in larvae and fry of both diploid and triploid animals.

\section{Materials and Methods}

\section{Animals}

Sea bass (D. labrax) eggs and milt were obtained from broodstock held in a fish farm at Pellestrina (Venice, Italy). Diploids and triploids were obtained as described by Colombo et al. ${ }^{8}$ Briefly, females were stimulated with a single dose of $10 \mu \mathrm{gg}^{-1}$ of $\mathrm{GnRH}$ analogue des-Gly ${ }^{10}$, [D-Ala ${ }^{6}$-LH-RH ethylamide (Sigma, USA). Males were not hormonally
Correspondence: Giuseppe Radaelli, Department of Experimental Veterinary Sciences, University of Padua, Italy.

Tel: +39.049.790165, Fax: +39.049.641174.

E-mail: giuseppe.radaelli@unipd.it

Key words: IGF-I, IGF-II, MSTN, immunohistochemistry, triploid.

Acknowledgements: the authors wish to thank the team of the Pellestrina fish farm (Veneto Agricoltura, Italy). This research was supported by grants from the Italian Ministero dell'Università e della Ricerca Scientifica e Tecnologica (MIUR) and of the University of Padua (Progetto di Ateneo).

Received for publication: 23 December 2009. Accepted for publication: 12 February 2010.

This work is licensed under a Creative Commons Attribution 3.0 License (by-nc 3.0).

CCopyright G. Radaelli et al., 2010 Licensee PAGEPress, Italy

European Journal of Histochemistry 2010; 54:e16 doi:10.4081/ejh.2010.e16

treated. Nearly 50-60 h after hormone treatment, fish were netted, anaesthetized and gametes were collected by a gentle abdominal compression in both males and females. Within 5 min from fertilization, eggs were rapidly rinsed from sperm and submitted to a cold shock $\left(0-2^{\circ} \mathrm{C}\right)$ for $20 \mathrm{~min}$ to prevent the extrusion of the second polar body. An equivalent part of fertilized egg mass was untreated and used as diploid control. Ploidy of animals was determined by flow-cytometry assessment of the nuclear DNA content in in toto larvae..$^{55}$

Diploid and triploid eggs were reared, till hatch, into two different $80 \mathrm{~L}$ incubators, under the same hydrological conditions (temperature range: $15.5-22.8^{\circ} \mathrm{C}$ ). Larvae hatched in $36 \mathrm{~h}$ and, after yolk sack absorption, were transferred into two separate $1 \mathrm{~m}^{3}$ tank and fed accordingly to rearing protocol. At 2, 6, 10, 30, $45,60,74$ days post hatch (dph) a pool of larvae from each ploidy was sampled and euthanasized with a lethal dose of MS-222 (Sandoz, Italy).

\section{Growth performance}

At each age class (except at $2 \mathrm{dph}$ ), the standard length (LS, the distance from snout to the tip of the notochord or hypural plate) of 10-12 larvae or juveniles per ploidy was measured under a binocular microscope.

\section{Fixation and embedding}

Animals were fixed in 4\% paraformaldehyde prepared in phosphate-buffered saline (PBS, 
$0.1 \mathrm{M}, \mathrm{pH} 7.4$ ) at $4^{\circ} \mathrm{C}$ overnight, washed in PBS, dehydrated through a graded series of ethanol and embedded in paraffin. Sections were cut at a thickness of $4 \mu \mathrm{m}$ using a microtome.

\section{Immunohistochemical procedure}

All the antibodies used for this study are detailed in Table 1. Immunohistochemical staining was done using the Elite ABC KIT system (Vector Laboratories, Inc., Ca, USA). Before applying the primary antibody, endogenous peroxidase activity was blocked by incubating the sections in $3 \% \mathrm{H}_{2} \mathrm{O}_{2}$ in PBS. The non-specific binding sites were blocked by incubating the sections in normal goat serum (Dako, Italy). Then, sections were incubated with specific primary antisera (see Table 1) overnight at $4^{\circ} \mathrm{C}$. After washing with PBS, sections were incubated with biotin-conjugated anti-mouse Ig antibodies (Dako), washed with PBS and reacted with peroxidase-labeled avidin-biotin complex (Vector Laboratories, Inc., $\mathrm{Ca}$, USA). The immunoreactive sites were visualized using diaminobenzidine (DAB) (Sigma, Italy) as the chromogen. To ascertain structural details, sections were counterstained with Mayer's haematoxylin.

\section{Controls}

The specificity of the immunostaining was verified by incubating sections with: i) PBS instead of the specific primary antibodies (see Table 1); ii) preimmune sera instead of the primary antisera; iii) PBS instead of the secondary antibodies and iv) by absorption of the antisera with excess of synthetic peptides (3 $\mu \mathrm{g} / \mathrm{L})$ before incubation with sections. The results of these controls were negative (i.e. staining was abolished).

\section{Statistical analysis}

A Student's t-test for independent samples was used to determine any significant differences between mean LS of diploids and triploids at each age class. Statistical significance was taken as $\mathrm{P}<0.05$.

\section{Results}

\section{Ploidy in the examined animals}

All the putative triploid sea bass were characterized by 1.5 fold the nuclear DNA amount of the diploid fish (data not shown), thus confirming their triploid status and the success of triplodization.
Table 1. Antibodies used in the current study.

\begin{tabular}{|c|c|c|c|}
\hline Antibody name and origin & $\begin{array}{l}\text { Immunogen } \\
\text { and dilution }\end{array}$ & $\begin{array}{l}\text { Source and references } \\
\text { for use with fish tissues }\end{array}$ & Significance \\
\hline $\begin{array}{l}\text { Anti-IGF-I; mouse polyclonal } \\
\text { anti-insulin-like growth factor-I }\end{array}$ & $\begin{array}{l}\text { IGF-I from fish } \\
(S . \text { aurata }) 1: 100\end{array}$ & Perrot et al. ${ }^{21}$ & $\begin{array}{l}\text { Proliferation and } \\
\text { differentiation of } \\
\text { satellite cells, } \\
\text { induced during } \\
\text { muscle regeneration }\end{array}$ \\
\hline $\begin{array}{l}\text { Anti-IGF-II; mouse polyclonal } \\
\text { anti-insulin-like growth factor-II }\end{array}$ & $\begin{array}{l}\text { IGF-II from fish } \\
\text { (S. aurata) 1:500 }\end{array}$ & $\begin{array}{l}\text { EuroGentec, Belgium; } \\
\text { Radaelli et al. }{ }^{35}\end{array}$ & $\begin{array}{l}\text { Proliferation of } \\
\text { satellite cells, induced } \\
\text { during muscle } \\
\text { regeneration }\end{array}$ \\
\hline $\begin{array}{l}\text { Anti-MSTN; mouse polyclonal } \\
\text { anti-myostatin }\end{array}$ & $\begin{array}{l}\text { MSTN from fish } \\
\text { (S. aurata) 1:800 }\end{array}$ & $\begin{array}{l}\text { EuroGentec, Belgium; } \\
\text { Radaelli et al. }{ }^{47}\end{array}$ & $\begin{array}{l}\text { Expression of MSTN } \\
\text { precursor, occurring } \\
\text { soon after muscle } \\
\text { differentiation }\end{array}$ \\
\hline
\end{tabular}

Table 2. Immunohistochemical localization of IGF-I in diploids (D) and triploids (T) of sea bass.

\begin{tabular}{|c|c|c|c|c|c|c|c|c|c|c|c|c|}
\hline \multirow[t]{2}{*}{ Tissue } & \multicolumn{2}{|c|}{$2 \mathrm{dph}$} & \multicolumn{2}{|c|}{$6 \mathrm{dph}$} & \multicolumn{2}{|c|}{$10 \mathrm{dph}$} & \multicolumn{2}{|c|}{ 30-45 dph } & \multicolumn{2}{|c|}{60 dph } & \multicolumn{2}{|c|}{$74 \mathrm{dph}$} \\
\hline & D & $\mathrm{T}$ & D & $\mathrm{T}$ & D & $\mathrm{T}$ & D & $\mathrm{T}$ & D & $\mathrm{T}$ & D & $\mathrm{T}$ \\
\hline Gill epithelium & * & * & - & & & - & + & ++ & + & ++ & + & ++ \\
\hline Heart & * & * & $+/$ & $+/-$ & + +- & $+/-$ & + +- & $+/-$ & $+/-$ & + +- & $+/-$ & $+/-$ \\
\hline Gut epithelium & ++ & $+/-$ & ++ & ++ & + & + & + & ++ & + & ++ & + & ++ \\
\hline Liver & $*$ & $*$ & + & + & + & + & + & + & + & + & + & + \\
\hline Kidney & $*$ & & + & + & + & $+/-$ & $+/-$ & + & $+/-$ & + & $+/-$ & + \\
\hline Pancreas & $*$ & * & - & - & - & - & $+/-$ & $+/-$ & $+/-$ & +- & $+/-$ & $+/-$ \\
\hline Skin & + & + & ++ & ++ & + & + & ++ & ++ & + & + & + & + \\
\hline Skeletal muscle & ++ & + & ++ & ++ & + & + & + & ++ & $+/-$ & + & + & ++ \\
\hline
\end{tabular}

Staining: -, not detectable; +/-, slight but above background levels; + moderate; ++, marked staining. *Tissue not found on the sections examined at this stage.

Table 3. Immunohistochemical localization of IGF-II in diploids (D) and triploids (T) of sea bass.

\begin{tabular}{|c|c|c|c|c|c|c|c|c|c|c|c|c|}
\hline \multirow[t]{2}{*}{ Tissue } & \multicolumn{2}{|c|}{2 dph } & \multicolumn{2}{|c|}{$6 \mathrm{dph}$} & \multicolumn{2}{|c|}{$10 \mathrm{dph}$} & \multicolumn{2}{|c|}{$30-45 \mathrm{dph}$} & \multicolumn{2}{|c|}{60 dph } & \multicolumn{2}{|c|}{74 dph } \\
\hline & D & $\mathrm{T}$ & D & $\mathrm{T}$ & D & $\mathrm{T}$ & D & $\mathrm{T}$ & D & $\mathrm{T}$ & D & $\mathrm{T}$ \\
\hline Gill epithelium & $*$ & * & - & - & - & - & + & $+/-$ & + & + & + & $+/-$ \\
\hline Heart & $*$ & $*$ & - & - & - & - & + & $+/-$ & $+/-$ & $+/-$ & $+/-$ & $+/-$ \\
\hline Gut epithelium & + & $+/-$ & + & $+/-$ & ++ & ++ & + & + & $+/-$ & $+/-$ & $+/-$ & $+/-$ \\
\hline Liver & $*$ & $*$ & + & $+/-$ & $+/-$ & $+/-$ & + & $+/-$ & + & $+/-$ & + & $+/-$ \\
\hline Kidney & $*$ & $*$ & $+/-$ & - & $+/-$ & - & - & - & - & - & - & - \\
\hline Pancreas & $*$ & $*$ & - & - & - & - & - & - & - & - & - & - \\
\hline Skin & + & + & + & + & + & + & + & + & + & + & + & + \\
\hline Skeletal muscle & + & + & + & + & + & $+/-$ & $+/-$ & $+/-$ & $+/-$ & $+/-$ & $+/-$ & $+1-$ \\
\hline
\end{tabular}

Staining: -, not detectable; +/-, slight but above background levels; + moderate; ++, marked staining. *Tissue not found on the sections examined at this stage. 


\section{Growth performance}

Mean values of LS in diploid and triploid fish for each age are shown in Figure 1.

The statistical analysis highlighted a difference only in $30 \mathrm{dph}$ fish with triploids significantly greater than diploids $(\mathrm{P}<0.01)$.

\section{Immunohistochemical localization of IGF-I, IGF-II and MSTN proteins}

\section{General}

Immunohistochemical localization of IGF-I, IGF-II and MSTN in different tissues of diploid and triploid sea bass is summarized in Tables 2-4.

\section{IGF-I}

In larvae aged 2 days, IGF-I immunoreactivity was detected in the epithelia of developing intestine and skin, as well as in lateral muscle and yolk sac of both diploids and triploids (Table 2). In larvae aged 6 days, skeletal muscle of both diploids and triploids showed a marked immunostaining (Figure 2A, B). At this developmental stage, a marked immunoreactivity was also observed in the epithelia of gut and skin (Table 2). In larvae aged 6-10 days, a moderate immunostaining was also detected in liver and developing kidney, whereas heart musculature exhibited a faint reactivity (Table 2). From day 30, skeletal muscle as well as the epithelia of gills, gut and kidney of triploids exhibited an immunoreactivity higher than the one of diploids (Table 2, Figure 2C-F).

\section{IGF-II}

In both diploids and triploids aged 2 days, a moderate IGF-II immunostaining was observed in the epithelia of skin and developing intestine (Table 3), as well as in skeletal muscle (Figure 3A, B). At this developmental stage, a faint IGF-II immunoreactivity was also observed in the yolk sac (Table 3). From day 6 , IGF-II reactivity was also detected in liver of both diploids and triploids and in developing kidney of diploids (Table 3). From day 30, heart musculature and gill epithelium exhibited an IGF-II immunostaining, whereas no reactivity was detected in kidney (Table 3). At all stages, tissues exhibited an IGF-II immunostaining ranging from faint to moderate, although the gut epithelium of larvae aged 10 days showed a marked reactivity (Table 3, Figure 3C, D). No significant differences between diploids and triploids were observed in immunoreactivity.

\section{MSTN}

In both diploids and triploids aged 2-10 days, a MSTN immunostaining was observed in skeletal muscle and in the epithelia of skin and developing intestine (Table 4, Figure 4A-F). From day 6, MSTN immunoreactivity was also

Table 4. Immunohistochemical localization of MSTN in diploids (D) and triploids (T) of sea bass.

\begin{tabular}{|c|c|c|c|c|c|c|c|c|c|c|c|c|}
\hline \multirow{2}{*}{ Tissue } & \multicolumn{2}{|c|}{$2 \mathrm{dph}$} & \multicolumn{2}{|c|}{$6 \mathrm{dph}$} & \multicolumn{2}{|c|}{$10 \mathrm{dph}$} & \multicolumn{2}{|c|}{$30-45 \mathrm{dph}$} & \multicolumn{2}{|c|}{$60 \mathrm{dph}$} & \multicolumn{2}{|c|}{$74 \mathrm{dph}$} \\
\hline & D & $\mathrm{T}$ & D & $\mathrm{T}$ & D & $\mathrm{T}$ & D & $\mathrm{T}$ & D & $\mathrm{T}$ & D & $\mathrm{T}$ \\
\hline Gill epithelium & * & $*$ & - & - & - & - & + & $+/-$ & + & $+/-$ & + & $+/-$ \\
\hline Heart & * & $*$ & + +- & - & $+/-$ & - & $+/-$ & + +- & $+/-$ & $+/-$ & $+/-$ & $+/-$ \\
\hline Gut epithelium & + & + & $+/-$ & + & ++ & $+/-$ & + & + & + & + & + & + \\
\hline Liver & * & $*$ & + & $+/-$ & $+/-$ & - & +- & - & $+/-$ & - & $+/-$ & - \\
\hline Kidney & * & $*$ & $+/-$ & - & $+/-$ & - & $+/-$ & - & $+/-$ & $+/-$ & $+/-$ & $+/-$ \\
\hline Pancreas & * & $*$ & - & - & $+/-$ & + & - & - & - & - & - & - \\
\hline Skin & + & + & + & + & + & + & + & $+/-$ & + & $+/-$ & + & $+/-$ \\
\hline Skeletal muscle & + & + & + & + & +- & +- & + & +- & $+/-$ & $+/$ & + & + +- \\
\hline
\end{tabular}

Staining: - , not detectable; +/-, slight but above background levels; + moderate; ++, marked staining. *Tissue not found on the sections examined at this stage.

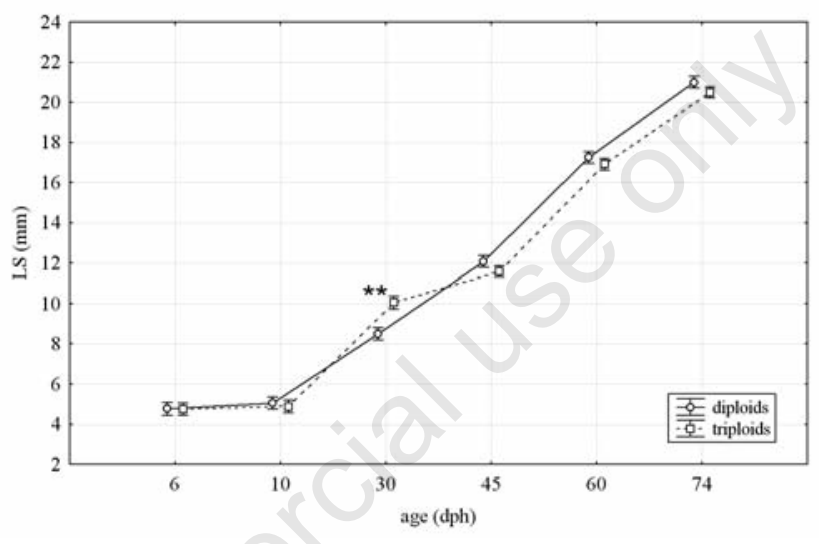

Figure 1. Mean standard length of diploid and triploid fish at each age class. Vertical bars represent standard errors of the mean and asterisks indicate significant difference between groups.

detected in liver, heart musculature and in developing kidney, although the staining was different between diploids and triploids (Table 4, Figure 4C-F). Pancreas exhibited a MSTN immunostaining only in larvae aged 10 days (Figure 4F). From day 30 the epithelium covering gill filament was stained, too (Table 4). No significant differences between diploids and triploids were observed in immunoreactivity.

\section{Discussion}

The present study reports novel information on the cellular localization of IGF-I, IGF-II and MSTN proteins during development and growth of diploid and triploid sea bass ( $D$. labrax). Although triploids are morphologically similar to diploids, they have larger but fewer cells in most tissues and organs and they are sterile, thus increasing their appealing for aquaculture as a mean to protect somatic growth, survival and flesh quality from the negative effects of sexual maturation. .,6,56 $^{\circ}$

A general opinion is that triploids should grow faster than diploids, since their genes are more numerous and their cells are larger ${ }^{56}$ However, the literature concerning the growth performance of triploids and their diploid counterparts is often contradictory. Several studies have reported that growth of triploid fish was similar to the diploids one, during the juvenile period, ${ }^{3,10,57-59}$ whereas it was higher at their sexual maturation time. ${ }^{60-63}$ Moreover, Razak et al. ${ }^{64}$ found that transgenic diploids of tiliapia were superior in growth performance, followed by transgenic triploids, non transgenic diploids and non transgenic triploids. In terms of growth performance, the literature of triploids is mainly limited to the evaluation of growth rate and fork length, whereas no papers report on the cellular localization of growth factors, such as IGFs and MSTN, during ontogenesis. In the present study the cellular localization of IGF-I, IGF-II and MSTN proteins was studied from hatching to juvenile stages by immunohistochemistry using polyclonal antisera raised against sea bream IGF-I, ${ }^{21}$ IGF-II ${ }^{35}$ and MSTN ${ }^{47}$ In general, the cellular sites of immunoreactivity observed in triploids were identical to those found in diploids for all tested antibodies.

\section{Cellular localization of IGF-I}

The pattern of immunostaining for IGF-I observed in both diploids and triploids was 
similar to that observed in diploids of $S$. aura$t a,{ }^{21}$ U. cirrosa ${ }^{23,27}$ D. labrax ${ }^{28}$ demonstrating that the sequence similarity between IGF-I from different fish species is sufficient to allow cross-species immunoreactivity. A similar pattern of immunostaining was also observed in 0 . niloticus by Berishvili et al. ${ }^{26}$

During early larval life, IGF-I immunoreactivity was mainly detected in the epithelia of gut, skin and kidney, as well as in skeletal musculature and liver. No significant differences between diploids and triploids were observed in immunoreactivity. Interestingly, from day 30, skeletal muscle and the epithelia of gills, gut and renal tubules of triploids exhibited an immunostaining higher than that of diploids. In our experimental conditions, the growth of triploids measured in terms of standard length was similar to that of diploids, although at day 30 triploids exhibited a significantly higher length. As mentioned above, triploid fish have larger but fewer cells in their tissues and the reduction in the cell number could be compensated by a higher protein synthesis..$^{56}$ In fish, body growth is mainly correlated to that of skeletal lateral muscle, which continues to grow significantly even into juvenile life in many species, through continuous hyperplasia and hypertrophy. ${ }^{65}$ Johnston et $a l .{ }^{66}$ found that triploid Salmonidae exhibited a reduced hyperplasia as a consequence of a decrease in the satellite cell number. They suggested that the reduced number of myocytes detected in triploids was compensated by their rates of hypertrophic growth, greater than the diploids ones. ${ }^{66}$

Moreover, Alonso et al. ${ }^{67}$ observed that during fin regeneration of 0 . mykiss, the protein synthesis (per unit muscle mass) was higher in triploids than in diploids.

\section{Cellular localization of IGF-II}

In our previous immunohistochemical study, the use of an antiserum raised against sea bream IGF-II gave us the possibility to detect the cellular distribution of IGF-II protein in D. labrax ${ }^{28}$, as well as in U. cirrosa ${ }^{27}$ demonstrating that there is a high degree of similarity between IGF-II proteins from different fish species and therefore allows cross-species immunoreactivity.

In young larvae, IGF-II immunostaining was found in skeletal muscle, liver, the epithelia of skin and developing intestine of both diploids and triploids, as well as in the epithelium of renal tubules of diploids. From day 30, heart musculature and the epithelium of gill filaments exhibited an IGF-II immunostaining. The pattern of IGF-II immunopositivity was similar to the one observed in diploids of several fish species..$^{21,27,35,40}$ However, in the present work we did not observe significant differences between diploids and triploids in terms
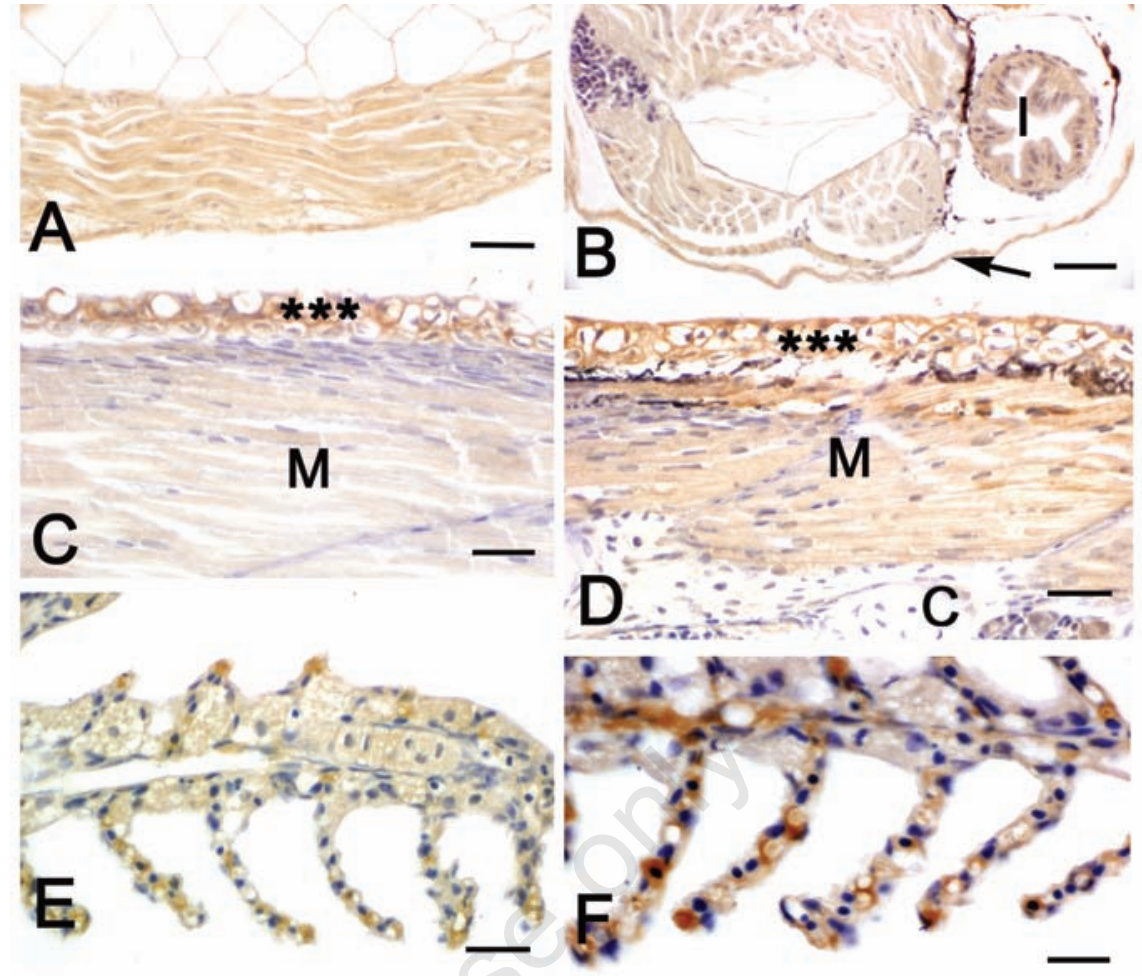

Figure 2. Immuno-histochemical localization of IGF-I in sea bass larvae and fry. All panels are counter-stained with haematoxylin. A, C, E: diploid animals; B, D, F: triploid animals. A Sagittal section of a 6-day larva. A marked IGF-I immunostaining is present in the trunk musculature. B Transverse section of a 6-day larva. A marked IGF-I immunostaining is present in the trunk musculature, intestine (I) and skin (arrow). C-D Sagittal sections of 45-day larvae. Skin epithelium (asterisks) exhibits a marked positivity in both diploids and triploids. An immunostaining is also present in skeletal muscle (M), although in triploids (D) the reactivity is stronger than in diploids (C). Cartilage (c) is negative. E-F Gills of 60-day fry. Immunostaining is present in the epithelium of the gill filaments and the reactivity is stronger in triploids $(\mathrm{F})$ than in diploids (E). Bars (A) 20 $\mu \mathrm{m}$, (B) $20 \mu \mathrm{m}$, (C) $15 \mu \mathrm{m}$, (D) $15 \mu \mathrm{m}$, (E) $12.5 \mu \mathrm{m}$, (F) $12.5 \mu \mathrm{m}$.

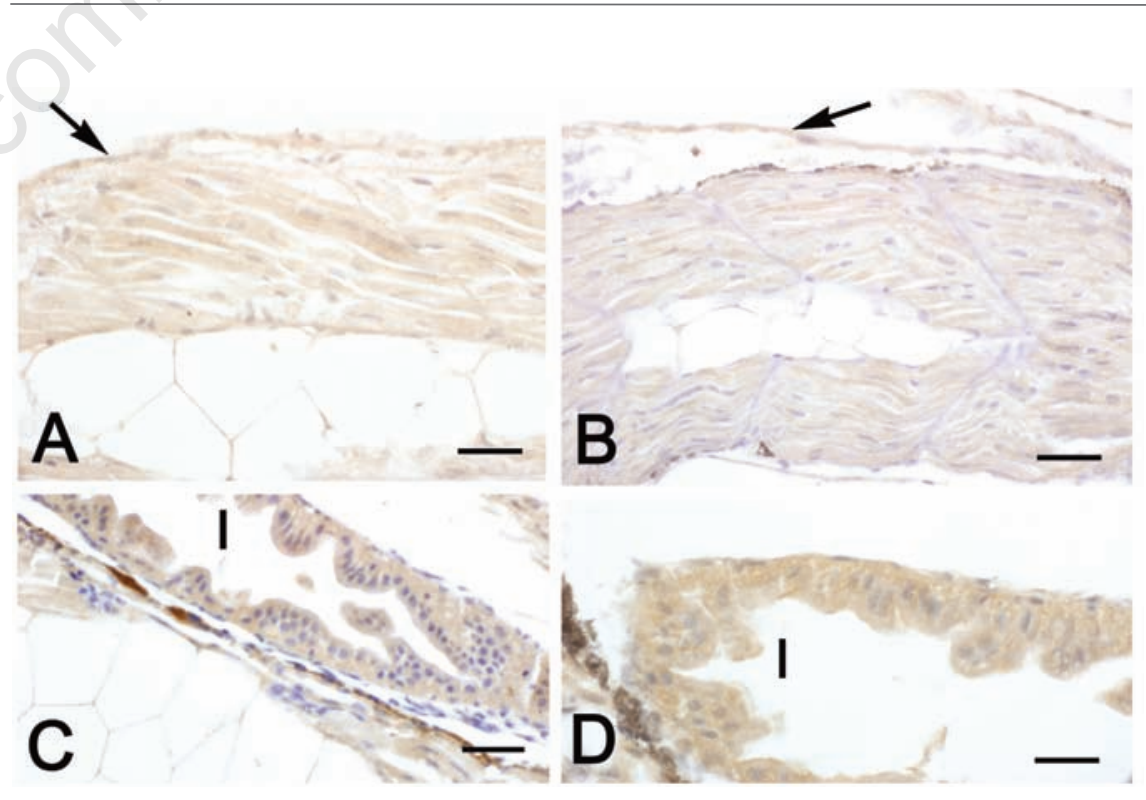

Figure 3. Immunohistochemical localization of IGF-II in sea bass larvae. All panels are counterstained with haematoxylin. A, C: diploid animals; B, D: triploid animals. A-B Sagittal sections of 2-day larvae. In both diploids and triploids a moderate immunostaining is present in skeletal muscle and skin (arrows). C-D Sections of 10-day larvae. In both diploids and triploids a marked immunostaining is detectable in the intestinal epithelium (I). Bars (A) $15 \mu \mathrm{m}$; (B) $20 \mu \mathrm{m}$, (C) $20 \mu \mathrm{m}$, (D) $12.5 \mu \mathrm{m}$. 


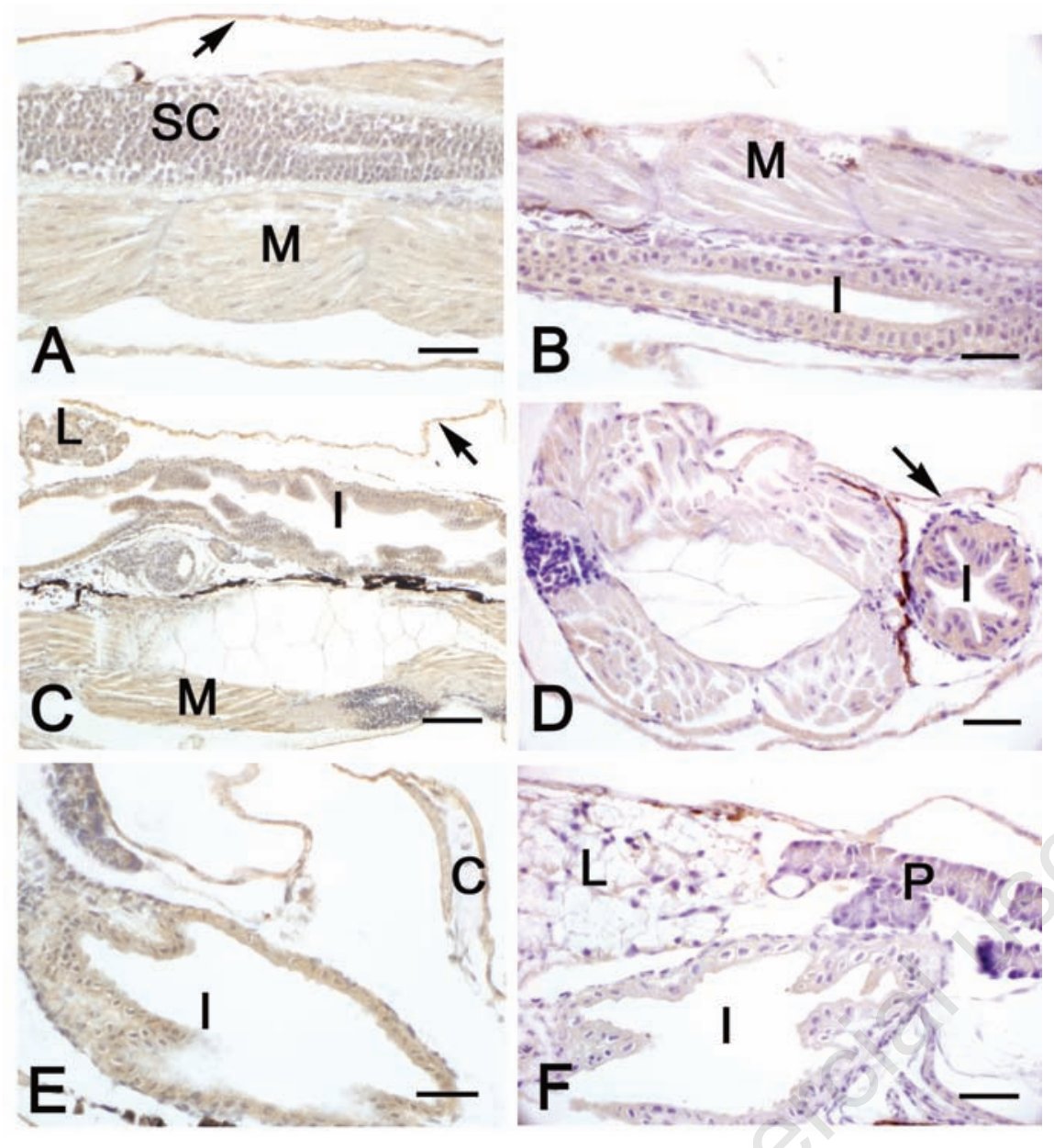

Figure 4. Immunohistochemical localization of MSTN in sea bass larvae. All panels are counter-stained with haematoxylin. A, C, E: diploid animals; B, D, F: triploid animals. AB Sagittal sections of 2-day larvae. In both diploids (A) and triploids (B), a moderate immunostaining is found in the epithelium of developing intestine (I), in skeletal muscle (M) and in the epithelium of skin (arrow). Spinal cord (SC) is negative. C-D) Sections of 6-day larvae of both diploids (C) and triploids (D), showing a moderate immunoreactivity in skeletal muscle (M), intestinal epithelium (I), liver (L) and skin (arrows). E-F Sagittal sections of 10-day larvae of both diploids (E) and triploids (F), showing immunostaining in intestinal epithelium (I) and pancreas $(\mathrm{P})$. Cartilage (c) is negative. $\mathrm{L}$ : liver. Bars (A) $20 \mu \mathrm{m}$, (B) $20 \mu \mathrm{m}$, (C) $40 \mu \mathrm{m}$, (D) $20 \mu \mathrm{m}$, (E) $20 \mu \mathrm{m}$, (F) $20 \mu \mathrm{m}$.

of IGF-II immunoreactivity, suggesting that a similar amount of IGF-II protein is detectable in the tissues of both diploids and triploids.

\section{Cellular localization of MSTN}

The high degree of similarity between MSTNs from different fish species allowed us to use an antiserum raised against sea bream MSTN to detect the cellular distribution of the protein in different fish species, including $D$. labrax. ${ }^{28,40}$ In the present work, the pattern of MSTN immunostaining was similar to the one observed for IGF-I and IGF-II. A co-localization of IGF-I, IGF-II and MSTN proteins has been observed in cultured muscle explants from $S$. aurata ${ }^{54}$ suggesting an autocrine-paracrine action of these factors in regulating development and growth of fish. As for IGF-II, we did
PCR, the IGF-I espression in these tissues, in mind to better understand whether triploidy can result in any growth advantage.

\section{References}

1. Utter FM, Johnson OW, Thorgaard GH, Rabinovitch PS. Measurement and potential applications of induced triploidy in Pacific salmon. Aquaculture 1983;35:12535 .

2. Ihssen PE, McKay LR, McMillan I, Phillips RB. Ploidy manipulation and gynogenesis in fishes: cytogenetic and fisheries applications. Trans Am Fish Soc 1990;119:698717.

3. Felip A, Zanuy S, Carrillo M, Piferrer F. Induction of triploidy and gynogenesis in teleost fish with emphasis on marine species. Genetica 2001;111:175-95.

4. Ballarin L, Dall'Oro M, Bertotto D, Libertini A, Francescon A, Barbaro A. Haematological parameters in Umbrina cirrosa (Teleostei, Sciaenidae): a comparison between diploid and triploid specimens. Comp Biochem Physiol A Mol Integr Physiol 2004;138:45-51.

5. Piferrer F, Beaumont A, Falguière J-C, Flaj $\square$ hans M, Haffray P, Colombo L. Polyploid fish and shellfish: Production, biology and applications to aquaculture for performance improvement and genetic containment. Aquaculture 2009;293:125-156.

6. Benfey TJ. The physiology and behavior of triploid fishes. Rev Fish Sci 1999;7:39-67.

7. Felip A, Piferrer F, Zanuy S, Carrillo M. Comparative growth performance of diploid and triploid sea bass over the first four spawning seasons. J Fish Biol 2001;58:76-88.

8. Colombo L, Barbaro A, Libertini A, Benedetti P, Francescon A, Lombardo I. Artificial fertilization and induction of triploidy and meiogynogenesis in the European sea bass Dicentrarchus labrax L. J Appl Ichthyol 1995;11:118-25.

9. Peruzzi S, Chatain B. Pressure and cold shock induction of meiotic gynogenesis and triploidy in the European sea bass, Dicentrarchus labrax L.: relative efficiency of methods and parental variability. Aquaculture 2000;189:23-37.

10. Felip A, Zanuy S, Carrillo M, Piferrer F. Growth and gonadal development in triploid sea bass (Dicentrarchus labrax L.) during the first 2 years of age. Aquaculture 1999;173:389-99.

11. Castillo J, Codina M, Martinez ML, Navarro I, Gutiérrez J. Metabolic and mitogenic effects of IGF-I and insulin on muscle cells of rainbow trout. Am J Physiol Regul Integr 
Comp Physiol 2004; 286:935-41.

12. Terova G, Bernardini G, Binelli G, Gornati $\mathrm{R}$, Saroglia M. cDNA encoding sequences for myostatin and FGF6 in sea bass (Dicentrarchus labrax, L.) and the effect of fasting and refeeding on their abundance levels. Domest Anim Endocrinol 2006;30: 304-19.

13. Montserrat N, Gabillard JC, Capilla E, Navarro MI, Gutiérrez J. Role of insulin, insulin-like growth factors, and muscle regulatory factors in the compensatory growth of the trout (Oncorhynchus mykiss). Gen Comp Endocrinol 2007;150: 462-72.

14. Lee CY, Hu SY, Gong HY, Chen MHC, Lu JK, Wu JL. Suppression of myostatin with vector-based RNA interference causes a double-muscle effect in transgenic zebrafish. Biochem Biophys Res Commun 2009; 387:766-71.

15. Peter RE, Marchant TA. The endocrinology of growth in carp and related species. Aquaculture 1995;129:299-321

16. Reinecke M, Collet $\mathrm{C}$. The phylogeny of the insulin-like growth factors. Int Rev Cytol 1998; 183: 1-94.

17. Moriyama S, Ayson FG, Kawauchi H. Growth regulation by insulin-like growth factor-I in fish. Biosci Biotech Biochem 2000;64:1553-62.

18. Duan C. Nutritional and developmental regulation of insulin-like growth factor in fish. J Nutr 1998;128:306S-14.

19. Funkenstein B, Almuly R, Chan SJ. Localization of IGF-I and IGF-I receptor mRNA in Sparus aurata larvae. Gen Comp Endocrinol 1997;107:291-303.

20. Reinecke M, Schmid A, Ermatinger R, Loffin-Cueni D. Insulin-like growth factor I in the teleost Oreochromis mossambicus, the tilapia: gene sequence, tissue expression, and cellular localization. Endocrinology 1997;138:3613-19.

21. Perrot V, Moiseeva EB, Gozes Y, Chan SJ, Ingleton P, Funkenstein B. Ontogeny of the insulin-like growth factor system (IGF-I, IGF-II, and IGF-IR) in gilthead seabream (Sparus aurata): expression and cellular localization. Gen Comp Endocrinol 1999; 116:445-60.

22. Schmid AC, Naf E, Kloas W, Reinecke M. Insulin-like growth factor-I and -II in the ovary of a bony fish, Oreochromis mossambicus, the tilapia: in situ hybridisation, immunohistochemical localisation, Northern blot and cDNA sequences. Mol Cell Endocrinol 1999;156:141-9.

23. Radaelli G, Domeneghini C, Arrighi S, Bosi G, Patruno M, Funkenstein B. Localization of IGF-I, IGF-I receptor and IGFBP-2 in developing Umbrina cirrosa (Pisces: Osteichthyes). Gen Comp Endocrinol
2003;130:232-44.

24. Reinecke M, Björnsson BT, Dickhoff WW, McCormick SD, Navarro I, Power DM et al. Growth hormone and insulin-like growth factors in fish: where we are and where to go. Gen Comp Endocrinol 2005; 142:20-24.

25. Wood AW, Duan C, Bern HA. Insulin-like growth factor signaling in fish. Int Rev Cytol 2005;243:215-85.

26. Berishvili G, Shved N, Eppler E, Clota F, Baroiller JF, Reinecke F. Organ-specific expression of IGF-I during early development of bony fish as revealed in the tila-pia, Oreochromis niloticus, by in situ hy-bridization and immunohistochemistry: indication for the particular importance of local IGF-I. Cell Tissue Res 2006; 325:287-301.

27. Patruno M, Maccatrozzo L, Funkenstein B, Radaelli G. Cloning and expression of insulin-like growth factors I and II in the shi drum (Umbrina cirrosa). Comp Biochem Physiol B Biochem Mol Biol 2006; 137:137-51.

28. Patruno M, Sivieri S, Poltronieri C, Sacchetto R, Maccatrozzo L, Martinello T et al. Real-time polymerase chain reaction, in situ hybridization and immunohistochemical localization of insulin-like growth factor-I and myostatin during development of Dicentrarchus labrax (Pisces: 0stei-chthyes). Cell Tissue Res 2008;331:643-58.

29. Duguay SJ, Lai-Zhang J, Steiner DF, Funkenstein B, Chan SJ. Developmental and tissue-regulated expression of IGF-I and IGF-II mRNAs in Sparus aurata. J Mol Endocrinol 1996;16: 123-32.

30. Collet C, Candy J, Richardson N, Sara V. Organisation, sequence and expression of the gene encoding IGF-II from barramundi (Teleosteii, Lates calcarifer). Biochem Genetics 1997;35:211-24.

31. Loffing-Cueni D, Schmid AC, Reinecke M. Molecular cloning and tissue expression of the insulin-like growth factor II prohormone in the bony fish Cottus scorpius. Gen Comp Endocrinol 1999;113:32-7.

32. Degger B, Richardson N, Collet C, Upton Z. Production, in vitro characterization, in vivo clearance, and tissue localization of recombinant barramundi (Lates calcarifer) insulin-like growth factor II. Gen Comp Endocrinol 2001;123:38-50.

33. Ayson FG, de Jesus EG, Moriyama S, Hyodo S, Funkenstein B, Gertler A et al. Differential expression of insulin-like growth factor I and II mRNAs during embryogenesis and early development in rabbitfish, Siganus guttatus. Gen Comp Endocrinol 2002;126:165-74.

34. Tse MC, Vong QP, Cheng CH, Chan KM. PCR-cloning and gene expression studies in common carp (Cyprinus carpio) insulin-like growth factor-II. Biochim Biophys Acta 2002;1575 63-74.

35. Radaelli G, Patruno M, Maccatrozzo L, Funkenstein B. Expression and cellular localization of insulin-like growth factor-II protein and mRNA in Sparus aurata during development. J Endocrinol 2003;178:28599.

36. Vong QP, Chan KM, Cheng CH. Quantification of common carp (Cyprinus carpio) IGF-I and IGF-II mRNA by real-time PCR: differential regulation of expression by GH. J Endocrinol 2003;178:513-21.

37. Caelers A, Berishvili G, Meli ML, Eppler E, Reinecke M. Establishment of a real-time RT-PCR for the determination of absolute amounts of IGF-I and IGF-II gene expression in liver and extrahepatic sites of the tilapia. Gen Comp Endocrinol 2004;137: 196-204.

38. Carnevali 0, Cardinali M, Maradonna F, Parisi M, Olivotto I, Polzonetti-Magni AM et al. Hormonal regulation of hepatic IGF-I and IGF-II gene expression in the marine teleost Sparus aurata. Mol Reprod Dev 2005;71:12-8.

39. Funes V, Asensio E, Ponce M, Infante C, Cañavate JP, Manchado M. Insulin-like growth factor I and II in the sole Solea senegalensis: cDNA cloning and quantitation of gene expression in tissues and during larval development. Gen Comp Endocrinol 2006;149:166-72.

40. Radaelli G, Poltronieri C, Bertotto D, Funkenstein B, Simontacchi C. Cellular localization of insulin-like growth factor-II protein in the sea bass (Dicentrarchus labrax) from hatching to adult. Histol Histopathol 2008;23:523-30.

41. Maccatrozzo L, Bargelloni L, Cardazzo B, Rizzo G, Patarnello T. A novel second myostatin gene is present in teleost fish. FEBS Lett 2001;509:36-40.

42. Maccatrozzo L, Bargelloni L, Radaelli G, Mascarello F, Patarnello T. Characterization of the myostatin gene in the gilthead sea bream (Sparus aurata): sequence, genomic structure, and expression pattern. Mar Biotechnol 2001b; 3: 224-230.

43. Østbye TK, Galloway TF, Nielsen C, Gabestad I, Bardal T, Andersen $\emptyset$. The two myostatin genes of Atlantic salmon (Salmo salar) are expressed in a variety of tissues. Eur J Biochem 2001;268 5249-57.

44. Rescan PY, Jutel I, Ralliere C. Two myostatin genes are differentially expressed in myotomal muscles of the trout (Oncorhynchus mykiss). J Exp Biol 2001; 204: 3523-29.

45. Roberts SB, Goetz FW. Differential skeletal muscle expression of myostatin across teleost species, and the isolation of multiple myostatin isoforms. FEBS Lett 2001; 
491:212-6.

46. Kocabas AM, Kucuktas H, Dunham RA, Liu Z. Molecular characterization and differential expression of the myostatin gene in channel catfish (Ictalurus punctatus). Biochim Biophys Acta 2002;1575:99-107.

47. Radaelli G, Rowlerson A, Mascarello F, Patruno M, Funkenstein B. Myostatin precursor is present in several tissues in teleost fish: a comparative immunolocalization study. Cell Tissue Res 2003;311: 239-50.

48. Gregory DJ, Waldbieser GC, Bosworth BG. Cloning and characterization of myogenic regulatory genes in three Ictalurid species. Anim Genet 2004;35:425-30.

49. Garikipati DK, Gahr SA, Rodgers BD. Identification, characterization, and quantitative expression analysis of rainbow trout myostatin-1a and myostatin-1b genes. J Endocrinol 2006;190:879-88.

50. Garikipati DK, Gahr SA, Roalson EH, Rodgers B.D. Characterization of rainbow trout myostatin-2 genes (rtMSTN-2a and $2 b)$ : genomic organization, differential expression, and pseudogenization. Endocrinology 2007;148:2106-15.

51. Ko CF, Chiou TT, Chen TT, Wu JL, Chen JC, $\mathrm{Lu}$ JK. Molecular cloning of myostatin gene and characterization of tissue-specific and developmental stage-specific expression of the gene in orange spotted grouper, Epinephelus coioides. Mar Biotechnol 2007;9:20-32.

52. De Santis C, Evans BS, Smith-Keune C, Jerry DR. Molecular characterization, tissue expression and sequence variability of the barramundi (Lates calcarifer) myostatin gene. BMC Genomics 2008;9:82-96.
53. Delgado I, Fuentes E, Escobar S, Navarro C, Corbeaux T, Reyes AE et al. Temporal and spatial expression pattern of the myostatin gene during larval and juvenile stages of the Chilean flounder (Paralichthys adspersus). Comp Biochem Physiol B Biochem Mol Biol 2008;151:197-202.

54. Funkenstein B, Balas V, Skopal T, Radaelli G, Rowlerson A. Long-term culture of muscle explants from Sparus aurata. Tissue Cell 2006;38:399-415.

55. Libertini A, Bertotto D. Una microtecnica per allestire campioni da singole larve di pesci teleostei per la diagnosi della ploidia tramite citometria a flusso. Lettere GIC 2004;13:9-12.

56. Maxime V. The physiology of triploid fish: current knowledge and comparisons with diploid fish. Fish Fisheries 2008;9:67-78.

57. Henken AM, Brunink AM, Richter CJJ. Differences in growth rate and feed utilization between diploid and triploid African catfish, Clarias gariepinus (Burchell 1822). Aquaculture 1987;63:233-42.

58. Habicht C, Seeb JE, Gates RB, Brock IR, Olito C. Triploid coho salmon outperform diploid and triploid hybrids between coho salmon and Chinook salmon during their first year. Can J Fish Aquat Sci 1994;51:31-7.

59. Hussain MG, Rao GPS, Humayun NMRandall CF, Penman DJ, Kime D et al. Comparative performance of growth, biochemical composition and endocrine profiles in diploid and triploid tilapia Oreochromis niloticus L. Aquaculture 1995;138:87-97.

60. Lincoln RF. The growth of female diploid and triploid plaice (Pleuronectes platessa) $\mathrm{x}$ flounder (Platichthys flesus) hybrids over one spawning season. Aquaculture 1981;25:259-68.

61. Wolters WR, Chrisman CL, Libey GS. Erythrocyte nuclear measurements of diploid and triploid channel catfish, Ictalurus punctatus (Rafinesque). J Fish Biol 1982;20:253-8.

62. Guo X, Hershberger WK, Myers JM. Growth and survival of intrastrain and interstrain rainbow trout (Oncorhynchus mykiss) triploids. J World Aqua Soc 1990;21:250-6.

63. Fast AW, Pewnim T, Keawtabtim R, Saijit R, Te FT, Vejaratpimol R. Comparative growth of diploid and triploid Asian catfish Clarias macrocephalus in Thailand. J World Aqua Soc 1995;26:390-5.

64. Razak SA, Hwang GL, Rahman MA, Maclean N. Growth performance and gonadal development of growth enhanced transgenic tilapia Oreochromis niloticus (L.) following heat-shock-induced triplody. Mar Biotechnol 1999;1:533-44.

65. Rowlerson A, Veggetti A. Cellular mechanisms of post-embryonic muscle growth in aquaculture species. In: Johnston IA, eds. Fish Physiology. Academic Press, London, 2001, Vol 18. pp. 103-140.

66. Johnston IA, Strugnell G, McCracken ML, Johnstone R. Muscle growth and development in normal-sex-ratio and all-female diploid and triploid Atlantic salmon. J Exp Biol 1999;202:1991-2016.

67. Alonso M, Tabata YA, Rigolino MG, Tsukamoto RY. Effect of induced triploidy on fin regeneration of juvenile rainbow trout, Oncorhynchus mykiss. J Exp Zool 2000; 287:493-502. 